\title{
Evaluasi Tutupan Terumbu Karang Berbasis Masyarakat Di Wilayah Kawasan Konservasi Perairan Daerah (KKPD) Kabupaten Aceh Selatan
}

\section{Evaluation of Community-Based Coral Reef Percent Cover At Aceh Selatan District Marine Protected Areas (Mpa)}

\author{
Samsul Bahri ${ }^{*}$, Dina Arya Purnama ${ }^{2}$, Syahru Syawal $^{3}$, Ikhsanul Khairi ${ }^{4}$ \\ ${ }^{1}$ Program Studi Ilmu Kelautan, Fakultas Perikanan dan Ilmu Kelautan, Universitas Teuku Umar, Aceh \\ Barat, Indonesia. \\ ${ }^{2,3}$ Balai Pengelolaan Sumberdaya Pesisir dan Laut (BPSPL) Padang, Kementerian Kelautan dan Perikanan, \\ Sumatera Utara. \\ ${ }^{4}$ Program Studi Perikanan, Fakultas Perikanan dan Ilmu Kelautan, Universitas Teuku Umar, Aceh Barat. \\ Indonesia \\ *Korespondensi : samsulbahri@utu.ac.id
}

\begin{abstract}
ABSTRAK
Masyarakat merupakan pelaku konservasi utama yang bersentuhan secara langsung dengan wilayah pesisir. Penelitian ini dilakukan bertujuan untuk menghitung persentase tutupan terumbu karang berbasis masyarakat. Partisipasi masyarakat dibentuk guna membangun komunikasi dan kesadaran terhadap lingkungan. Penelitian dilakukan di enam wilayah perairan pada enam kecamatan meliputi Tapak Tuan, Samadua, Meukek, Labuhan Haji Timur, Bakongan dan Bakongan Timur. Penelitian dilakukan dengan menggunakan metode manta tow yang merupakan metode survey terumbu karang berbasis masyarakat. Hasil penelitian menunjukkan persentase tutupan karang keras yang paling tinggi ditemukan pada wilayah perairan Meukek dan Bakongan Timur. Sementara tutupan karang keras yang paling rendah ditemukan pada wilayah perairan Bakongan. Keterlibatan masyarakat dalam upaya perlindungan memberikan dampak yang positif terhadap kesehatan terumbu karang. Adanya panglima laot menguatkan bentuk partisipasi masyarakat terhadap pengelolaan wilayah perairan di Aceh Selatan.
\end{abstract}

Kata kunci: Manta Tow, Terumbu Karang, Kawasan Konservasi Perairan Daerah, Aceh Selatan

\begin{abstract}
Communities are the main conservation subject who are in direct contact with coastal areas. This research was conducted to calculate the percentage of coral reef cover based on community. Community participation is formed to build communication and awareness of the environment. The research was conducted in six districts areas which covers Tapak Tuan, Samadua, Meukek, Labuhan Haji Timur, Bakongan and Bakongan Timur. The research was conducted using the manta tow method which is a community-based coral reef survey method. The results showed that the highest percentage of hard coral cover was found in the waters of Meukek and Bakongan Timur. Meanwhile, the lowest hard coral cover was found in the Bakongan waters. Community involvement in protection efforts has a positive impact on the health of coral reefs. The existence of a Panglima Laot strengthens the form of community participation in the management of water areas in South Aceh.
\end{abstract}

Key words: Manta Tow, Coral reef, Marine Protected Area, Aceh Selatan 


\section{PENDAHULUAN}

Indonesia adalah salah satu negara kepulauaun dengan wilayah perairan yang sangat luas dimana memiliki 17.480 pulau-pulau besar dan kecil serta garis pantai sepanjang $95.181 \mathrm{~km}$ (Bahri et al. 2019). Terumbu karang merupakan ekosistem utama yang terdapat di lautan yang menjadi penompang ekologi di lautan khususnya pada perairan dangkal (Susanto et al. 2015). Seiring dengan pertumbuhan populasi masyarakat dimana kebutuhan akan protein di laut meningkat menyebab tekanan yang besar terhadap ekosistem terumbu karang. Hal ini ditandai dengan tingginya aktifitas manusia pada wilayah pesisir yang memberikan dampak negatif terhadap ekosistem terumbu karang (Askar et al. 2018). Masyarakat pesisir merupakan komponen utama yang sangat berpengaruh terhadap keberlangsungan ekosistem terumbu karang. Hal ini karena masyarakat pesisir memiliki interkasi langsung dengan pesisir dan laut seperti pemanfaatan dan pengelolaannya (Najmi et al. 2020).

Aceh selatan merupakan salah satu wilayah pesisir yang termasuk dalam Kawasan Perlindungan Perairan Daerah yang meliputi perairan sekitar Kecamatan Labuhan Haji, Kecamatan Samadua, Kecamatan Bakongan, Kecamatan Bakongan Timur dan Kecamatan Trumon dengan luas mencapai lebih kurang 3.590,34 Hektar dengan usulan nomenklatur berupa Suaka Alam Perikanan (BPSPL-KKP, 2019). Wilayah Zona Inti memiliki luas 799,12 Hektar (22,2\% dari total luas), Zona Pemanfaatan seluas 42,11 Hektar dan Zona Perikanan Berkelanjutan seluas 2.749,11 Hektar. Keterlibatan masyarakat dalam pembentukan wilayah perlindungan merupakan kunci dari konservasi yang berkelanjutan. Dalam mengontrol berbagai aktifitas yang terjadi di laut guna menyeimbangkan aspek ekonomi dan ekologi maka dibutuhkan keterlibatan dan peran serta masyarakat dalam pengelolaan ekosistem terumbu karang (Yulianda et al. 2009). Penelitian ini dilakukan bertujuan untuk menghitung persentase tutupan terumbu karang pada enam wilayah perairan kecamatan berbasis masyarakat. Partisipasi masyarakat dibentuk guna membangun komunikasi dan kesadaran terhadap lingkungan. 


\section{METODE PENELITIAN}

\section{Waktu dan Tempat}

Penelitian evaluasi komunitas terumbu karang berbasis masyarakat dilaksanakan pada tanggal 1 hingga 5 September 2018 di enam wilayah perairan pada enam kecamatan yang terdapat di kabupaten Aceh Selatan meliputi perairan kecamatan Tapak Tuan, Samadua, Meukek, Labuhan Haji Timur, Bakongan dan Bakongan Timur.

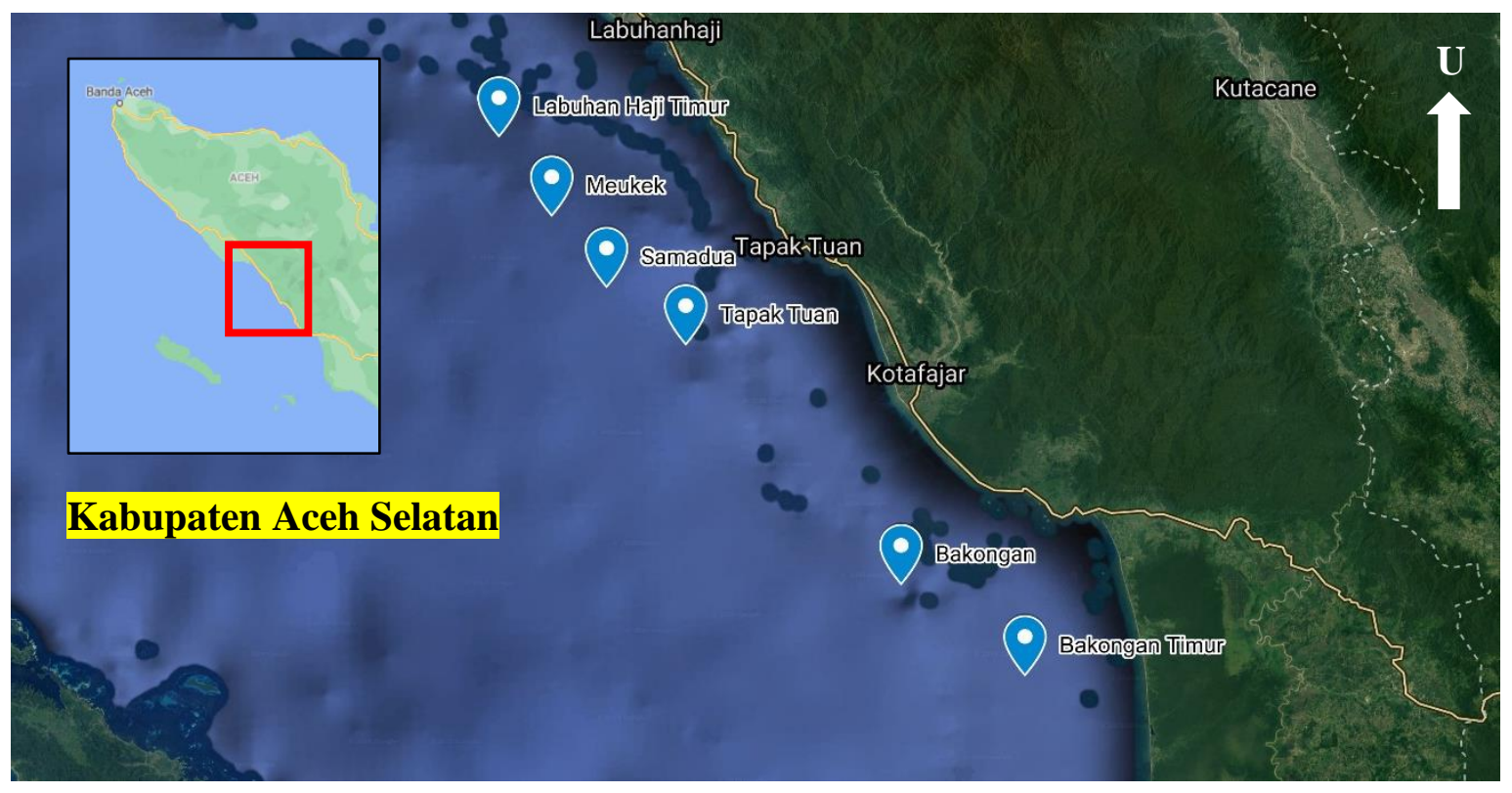

Gambar 1. Peta lokasi survey tutupan substrat perairan di kecamatan Labuhan Haji Timur, Meukek, Samadua, Tapak Tuan, Bakongan dan Bakongan Timur

\section{Pengambilan Data}

Pengambilan data terumbu karang dilakukan dengan menggunakan metoda Manta Tow (Fernandes et al. 1990). Metoda Manta Tow adalah suatu teknik pengamatan terumbu karang dengan cara pengamat di belakang perahu kecil bermesin dengan menggunakan tali sebagai penghubung antara perahu dengan pengamat. Dengan kecepatan perahu yang tetap dan melintas di atas terumbu karang dengan lama tarikan 2 menit, pengamat akan melihat beberapa obyek yang terlintas serta nilai persentase penutupan karang hidup (karang keras dan karang lunak) dan karang mati. Data yang diamati dicatat pada tabel data dengan menggunakan nilai kategori atau dengan nilai persentase bilangan bulat (Miller et al. 2003). 


\section{Analisis Data}

Penentuan persentase tutupan terumbu karang menggunakan pendekatan kategori yang memudahkan dalam penentuan jumlah persentase tutupan substrat (UNEP 1993). Adapun kategori persentase tutupan substrat meliputi Kategori 1 (0-10\%), Kategori 2 (11$30 \%)$, Kategori 3 (31-50\%), Kategori 4 (51-75\%) dan Kategori 5 (76-100\%).

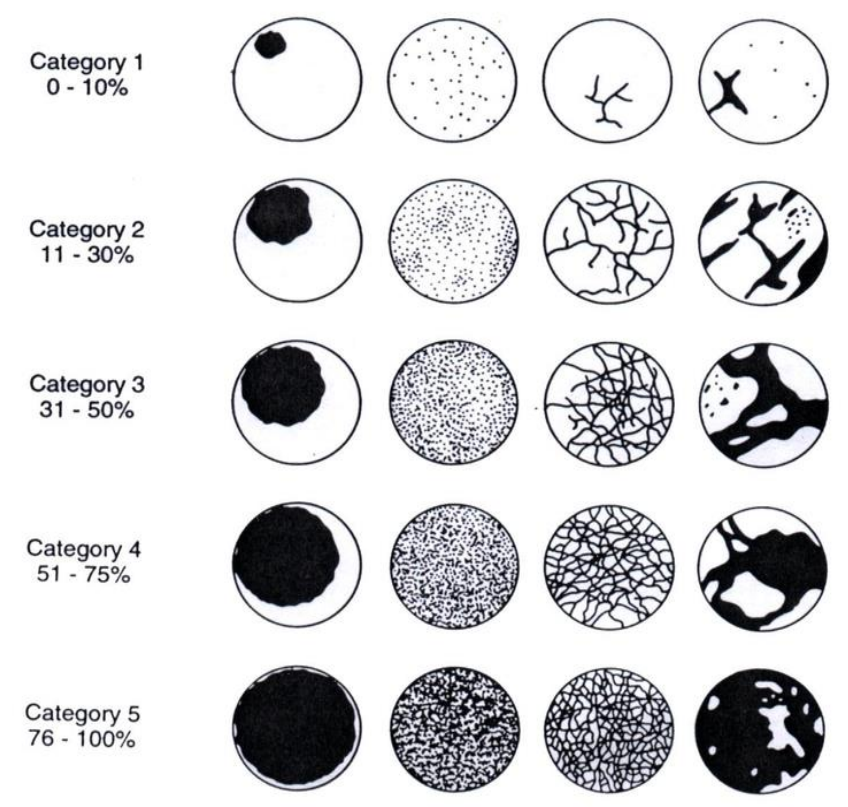

Gambar 2. Kategori persentase tutupan terumbu karang menggunakan metode Manta Tow

\section{HASIL DAN PEMBAHASAN}

Berdasarkan hasil pengamatan yang telah dilakukan maka diketahui persentase masing-masing substrat dari tutupan karang kerang keras (Hard coral-HCL), karang lunak (Soft coral-SC), karang mati (Dead coral-DC) dan tutupan pasir (Sand-SD). Nilai tutupan dari masing-masing tutupan bervariasi pada setiap lokasi dimana perbadaan persentase tutupan mengindikasikan kondisi keragaman terumbu karang. Adapun persentase masingmasing tutupan dapat dilihat pada gambar 3. 


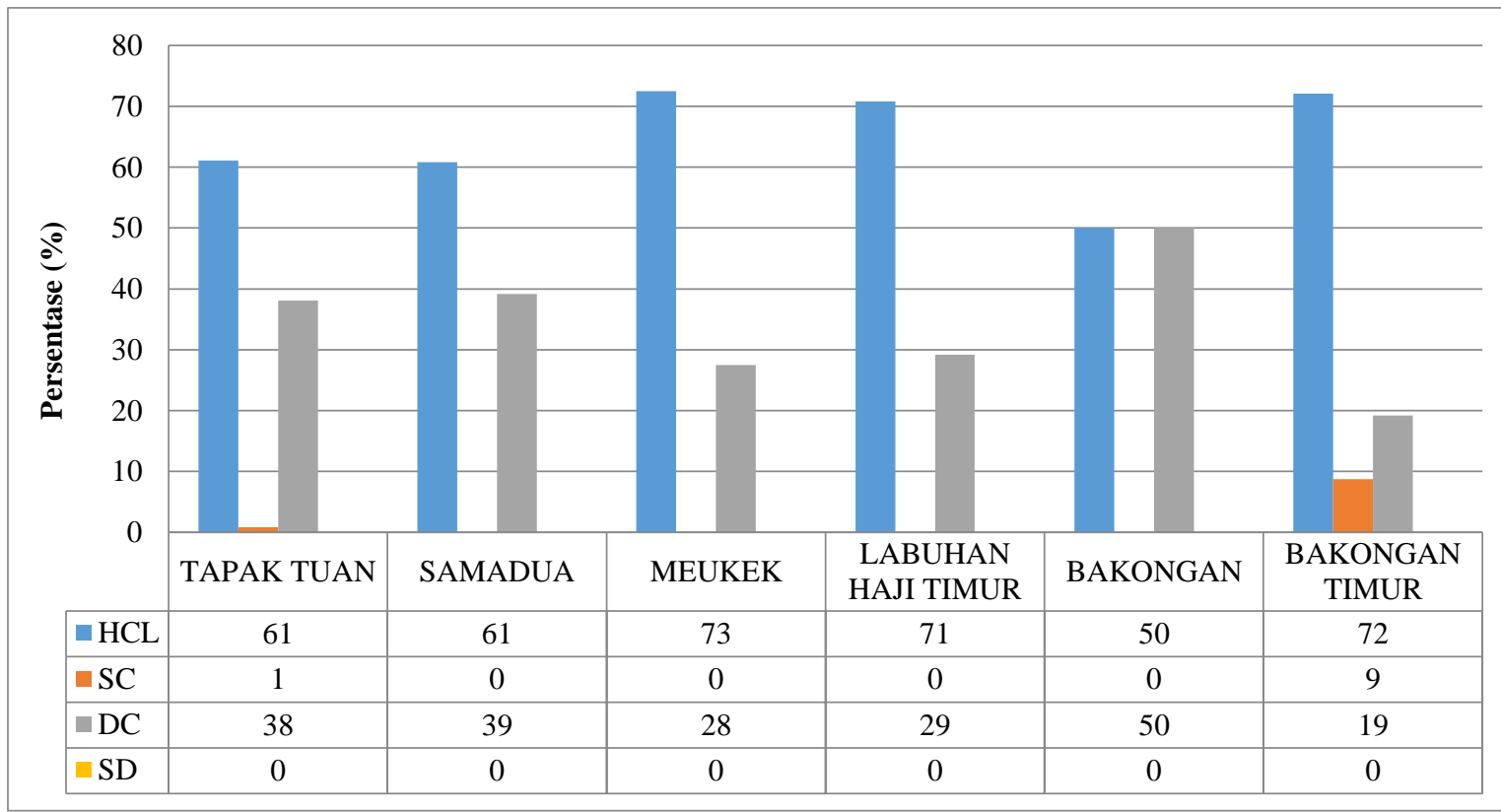

Gambar 3. Data persentase tutupan karang pada masing-masing lokasi pengamatan

Dari data hasil yang diperoleh ditemukan bahwa tutupan karang keras terbesar ditemukan di wilayah perairan Meukek dimana tutupan karang keras mencapai $73 \%$. Sementara tutupan karang keras yang paling kecil ditemukan pada wilayah perairan Bakongan dengan tutupan karang keras sebesar 50\%. Tutupan karang keras di wilayah perairan Meukek termasuk dalam kategori 4 dimana kisaran tutupan berada pada 51-75\%. Kondisi ini tergolong baik dimana banyak ditemukan tutupan karang keras yang masih hidup, selain itu juga didukung dengan rendahnya tutupan karang mati sebesar $28 \%$ dimana merupakan persentase tutupan karang mati yang paling sedikit dinatar lokasi pengamatan lainnya. Berdasarkan pengamatan lapangan yang telah dilakukan terlihat minimnya aktifitas penangkapan yang terjadi pada wilayah perairan ini. Minimnya kerusakan terumbu karang diasumsikan karena minimnya aktifitas manusia sehingga berkurangnya tekanan ekologi yang terjadi pada wilayah perairan ini. Kerusakan ekosistem terumbu karang umumnya disebabkan oleh aktifitas manusia yang menyebabkan tingginya tekanan terhadap suatu ekosistem (Mutmainah and Santa Clara 2017).

Tutupan karang keras di wilayah perairan Bakongan termasuk dalam kategori 3 dimana kisaran tutupan berada pada $31-50 \%$. Kondisi ini tergolong rendah dimana tutupan karang keras hanya sekitar 50\%, sementara sisanya ditutupi oleh karang yang telah mati. 
Tingginya aktifitas penangkapan ikan di perairan Bakongan ini diasumsikan menjadi penyebab rendahnya tutupan karang keras yang ada pada wilayah tersebut. Tekanan lingkungan yang terjadi secara kumulatif akan merusak ekosistem terumbu karang yang ada di suatu perairan (Santoso 2011). Aktifitas manusia secara terus menerus merupakan ancaman utama terhadap terumbu karang yang dapat menghambat pertubuhan terumbu karang (Bahri et al. 2015).

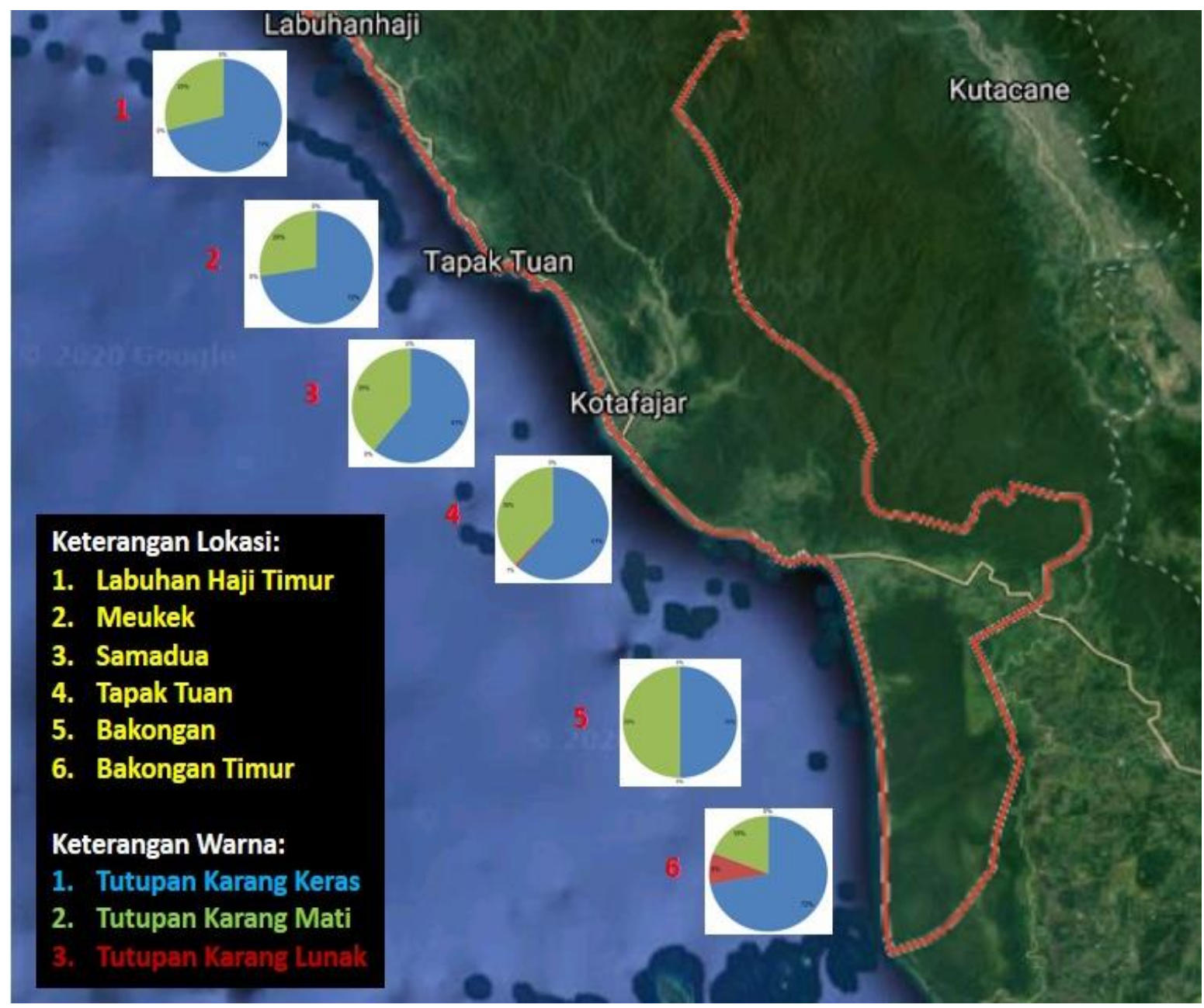

Gambar 4. Persentase tutupan karang pada masing-masing lokasi pengamatan

Kerusakan terumbu karang yang paling rendah ditemukan pada wilayah perairan Bakongan Timur dimana tutupan karang mati hanya berkisar 19\% serta didukung dengan tutupan karang keras sebesar $72 \%$. Selain itu juga ditemukan tutupan karang lunak sebesar 9\%. Adanya tutupan karang lunak menggambarkan tingginya keragaman biota yang 
terdapat pada wilayah ini. Pertumbuhan karang lunak sangat dipengaruhi oleh beberapa faktor seperti cahaya matahari, arus, suhu perairan dan salinitas (Sugiyanto 2004). Minimnya kerusakan karang pada wilayah ini disebabkan pengelolaan yang baik oleh masyarakat. Diketahui bawah panglima laot pada wilayah ini telah berkontribusi terhadap hukom adat laot yang mengatur tentang penangkapan ikan yang ramah lingkungan. Penegakan peraturan secara tegas akan membantu terhadap perlindungan ekosistem terumbu karang yang berdampak terhadap kesehatan terumbu karang (Muallil et al. 2015).

\section{KESIMPULAN}

Kondisi tutupan karang keras (HCL) yang paling tinggi ditemukan pada wilayah perairan kecamatan Meukek (73\%), Bakongan Timur (72\%) Dan Labuhan Haji Timur (71\%). Hal tersebut juga didukung dengan rendahnya tutupan karang mati pada ketiga wilayah tersebut berturut-turut adalah 28\%, 19\% dan 29\%. Tutupan karang mati (DC) paling rendah ditemukan pada lokasi bakongan timur yakni sebesar 19\%. Besarnya partisipasi masyarakat dan panglima laot dalam menerapkan hukom adat menjadi salah satu aspek yang membuat minimnya tekanan lingkungan pada wilayah perairan tersebut.

\section{UCAPAN TERIMAKASIH}

Ucapan terimakasih penulis sampaikan yang sebesar-besarnya kepada Kementerian Kelautan dan Perikanan (KKP) melalui Balai Pengelolaan Sumberdaya Pesisir dan Laut (BPSPL) Provinsi Padang yang telah mendanai kegiatan penelitian ini. Ucapan terimakasih juga penulis sampaikan kepada Ocean Diving Club (ODC) Universitas Syiah Kuala, Tapak Tuan Diving Club Aceh Selatan, Pusat Kajian Satwa Liar (PKSL) Universitas Syiah Kuala, Pemerintah Kabupaten Aceh Selatan yang telah terlibat dalam pelaksanaan teknis penelitian ini serta kepada seluruh masyarakat dan Panglima Laot Lhok di Kabupaten Aceh Selatan.

\section{DAFTAR PUSTAKA}

Askar, A.T., Agung, M.U.K., Andriani, Y. And Yuliadi, L.P. 2018. "Kelimpahan Bakteri Coliform Pada Air Laut, Sedimen Dan Foraminifera Jenis Calcarina Di Ekosistem Terumbu Karang Pulau Pramuka, Kepulauan Seribu, Dki Jakarta". Akuatika Indonesia, 3 (1): 36-41. 
Bahri, S., Heriansyah, H., Purnama, D.A., Erijal, E. And Rifki, M. 2019. "Biodiversitas Mangrove Di Perairan Aceh Barat Daya Sebagai Potensi Daerah Perlindungan Laut Berbasis Masyarakat". Jurnal Laot Ilmu Kelautan, 1 (2): 32-37.

Bahri, S., Rudi, E. And Dewiyanti, I. 2015. "Kondisi Terumbu Karang Dan Makro Invertebrata Di Perairan Ujong Pancu, Kecamatan Peukan Bada, Aceh Besar". Depik Jurnal Ilmu-Ilmu Perairan, Pesisir Dan Perikanan, 4(1).

Fernandes, L., Marsh, H., Moran, P. And Sinclair, D. 1990. "Bias In Manta Tow Surveys Of Acanthaster Planci". Coral Reefs, 9 (3): 155-160.

Miller, I., Jonker, M. And Coleman, G. 2003. Crown-Of-Thorns Starfish And Coral Surveys Using The Manta Tow And Scuba Search Techniques, Australian Institute Of Marine Science Townsville, Australia.

Muallil, R.N., Deocadez, M.R., Martinez, R.J.S., Mamauag, S.S., Nañola Jr, C.L. And Aliño, P.M. 2015. "Community Assemblages Of Commercially Important Coral Reef Fishes Inside And Outside Marine Protected Areas In The Philippines". Regional Studies In Marine Science, 1: 47-54.

Mutmainah, H. And Santa Clara, R. 2017. "Analisa Sebaran Tutupan Dan Indeks Mortalitas Terumbu Karang Di Perairan Sekitar Selat Pagai, Mentawai". Akuatika Indonesia, 2 (1): 43-57.

Najmi, N., Suriani, M., Rahmi, M.M., Islama, D. And Nasution, M.A. 2020. "Peran Masyarakat Pesisir Terhadap Pengelolaan Terumbu Karang Di Kawasan Konservasi Perairan Pesisir Timur Pulau Weh". Jurnal Perikanan Tropis, 7 (1): 73 84.

Santoso, A.D. 2011. "Teknologi Konservasi Dan Rehabilitasi Terumbu Karang". Jurnal Teknologi Lingkungan, 9 (3).

Sugiyanto, G. 2004. Pertumbuhan Dan Kelangsungan Hidup Karang (Caulastrea Furcata) Dengan Fragmentasi Buatan Di Perairan Pulai Pari Kepulauan Seribu, Tugas Akhir, FPIK-IPB, Bogor.

Susanto, H., Suraji, S. And Tokeshi, M. 2015. "Management Of Coral Reef Ecosystems In Indonesia: Past, Present And The Future". Coastal Ecosystem, 2: 21-41.

Unep, A. 1993. "Monitoring Coral Reefs For Global Change. Regional Seas. Reference Methods For Marine Pollution Studies", 61: 72.

Yulianda, F., Achmad, F., Armin, A., Sri, H. And Kusharjani, K. 2009. Ekologi Ekosistem Perairan Laut Tropis. Bogor: Pusdiklat Kehutanan Departemen Kehutanan Ri, Secem. 